\title{
Development of Primers for Improved PCR Detection of the Potato Zebra Chip Pathogen, 'Candidatus Liberibacter solanacearum'
}

Aravind Ravindran, Department of Plant Pathology and Microbiology, Julien Levy and Elizabeth Pierson, Department of Horticultural Sciences, and Dennis C. Gross, Department of Plant Pathology and Microbiology, Texas A\&M University, College Station 77843

\begin{abstract}
Ravindran, A., Levy, J., Pierson, E., and Gross, D. C. 2011. Development of primers for improved PCR detection of the potato zebra chip pathogen, 'Candidatus Liberibacter solanacearum'. Plant Dis. 95:1542-1546.

Zebra chip disease poses a major economic threat to potato production. The causative agent is a phloem-limited bacterium identified as 'Candidatus Liberibacter solanacearum' that is transmitted by the potato/tomato psyllid. Currently, there are no effective controls and existing control strategies depend largely on the early detection of the pathogen via polymerase chain reaction (PCR) assays. Most primer sets used for PCR detection target a region of the bacterial 16S rDNA gene, and detection of the pathogen in symptomatic potato tissue with existing primers has been variable depending on the specific primer sets used. This study describes the development of two new primer sets

that target a conserved intergenic region between the $16 \mathrm{~S}$ and $23 \mathrm{~S}$ rDNA genes and a conserved bacterial housekeeping gene, adenylate kinase $(a d k)$. Results demonstrate that the new primer sets are more reliable in detecting ' $\mathrm{Ca}$. L. solanacearum' in field and glasshouse samples than the currently used LsoF/OI2 primers. The newly developed primers differentiated between ' $\mathrm{Ca}$. L $\mathrm{L}$. solanacearum' and a closely related ' $\mathrm{Ca}$. Liberibacter' spp. and were more sensitive than the LsoF/OI2 primers. The low detection limit for the new primers was four times lower $(0.65 \mathrm{ng})$ than the limit $(2.5 \mathrm{ng})$ for the LsoF/OI2 primers.
\end{abstract}

Zebra chip disease (ZC) of potato poses a major economic threat to potato production in the United States, Mexico, and New Zealand $(14,20,25,33)$. Aboveground symptoms of ZC include stunting, leaf curling, chlorosis, swollen internodes, and aerial tubers. Belowground symptoms include reduced tuber production and tuber discoloration in the form of a light striped pattern in raw tubers that darkens when tubers are fried for chip production (20). Recently, it was demonstrated that ZC is caused by a nonculturable, phloem-limited bacterium identified as 'Candidatus Liberibacter solanacearum' (also known as ' $\mathrm{Ca}$. L. psyllaurous') that is transmitted by the potato/tomato psyllid, Bactericera cockerelli (Sulc.) $(3,6,12,14-16,25,33)$.

There are no effective control strategies for protecting plants from $\mathrm{ZC}$ and existing measures depend largely on the early detection and control of the psyllid vector (5). Accurate pathogen detection in the plant is essential for forecasting disease severity, is necessary for insect control, and, ultimately, helps reduce disease control costs. In the last decade, molecular approaches have significantly improved the detection, identification, and quantification of phytopathogenic microbes, especially those that are nonculturable and limited to vascular tissue (7). Current detection methods for ' $C a$. L. solanacearum' in plants rely primarily on polymerase chain reaction (PCR) assays, with primer sets located in the $16 \mathrm{~S}$ rDNA region $(3,6,12,15,16,25,33)$. This methodology has been somewhat unreliable in detecting the pathogen in symptomatic potato tissue and consistency of detection has been shown to vary with the primer sets used $(12,33)$.

Improvements in PCR detection require the development of new primer sets with high sensitivity and specificity sufficient to detect and distinguish between bacterial species, including closely related ' $\mathrm{Ca}$. Liberibacter' spp. in both plant and insect samples $(8,13,27)$. One approach is to develop primers that target the $16 \mathrm{~S} / 23 \mathrm{~S}$ rDNA intergenic region $(8,26,29)$. This intergenic region of bacteria

Corresponding author: D. C. Gross, E-mail: d-gross@tamu.edu

Accepted for publication 14 July 2011.

doi:10.1094/PDIS-05-11-0386

(C) 2011 The American Phytopathological Society exhibits greater variability in nucleotide composition relative to the 16S rDNA sequence and has been successfully used to improve the specificity of PCR detection of plant-pathogenic bacteria (17). A second approach is to target conserved bacterial "housekeeping genes". Because these genes are conserved across bacterial taxa, they have been employed in phylogenetic analyses (19,31). In recent years, incongruences between phylogenies inferred from $16 \mathrm{~S}$ rRNA sequence and phylogenies inferred from housekeeping genes have been revealed, which suggests the importance of using multiple targets to differentiate species $(21,30)$. The interspecific variation in housekeeping genes may provide useful targets for the development of species-specific probes or for designing primers for detection of pathogens of interest $(18,19,22)$.

This report describes the development of new primers that target a conserved intergenic region between the $16 \mathrm{~S}$ and $23 \mathrm{~S}$ rDNA genes and a conserved bacterial housekeeping gene, adenylate kinase ( $a d k)$, of ' $C a$. L. solanacearum'. The objectives of this study were to (i) demonstrate that the new primer sets can reliably detect ' $C a$. L. solanacearum' in ZC-infected potato plants, (ii) compare the abilities of the new primer sets and a currently used primer set to detect ' $\mathrm{Ca}$. L. solanacearum' in a large collection of field and glasshouse samples, (iii) test the specificity of the primer sets in differentiating two closely related ' $\mathrm{Ca}$. Liberibacter' spp., and (iv) compare the sensitivity of the primer sets over a range of DNA concentrations.

\section{Materials and Methods}

Plant materials and DNA samples. Tubers, roots, stems, petioles, and leaves of potato plants showing ZC symptoms were collected from commercial fields in Texas, Kansas, and Nebraska in the United States (Table 1). Also included were plants that were maintained in cages in a glasshouse and either exposed to or protected from bacterialiferous psyllids. The protected glasshouse plants served as ZC-negative controls.

DNA samples from citrus plants growing in Florida and India that were symptomatic for huanglongbing (HLB) disease caused by ' $\mathrm{Ca}$. L. asiaticus' were provided by Nian Wang, University of Florida, and included in PCR specificity assays.

Extraction of DNA for PCR. Total DNA was extracted from the different plant parts (tubers, roots, stems, petioles, and leaves) of ZC-symptomatic and healthy potato plants using a method modi- 
fied from Doyle and Doyle (4). Briefly, 0.5-mg samples of plant tissue were macerated in $1 \mathrm{ml}$ of a prewarmed extraction buffer (100 mM Tris-Cl, $50 \mathrm{mM}$ EDTA, and $1.4 \mathrm{M} \mathrm{NaCl}$ ). The ground samples were incubated at $65^{\circ} \mathrm{C}$ for $30 \mathrm{~min}$ in $1.5-\mathrm{ml}$ microfuge tubes containing $100 \mu \mathrm{l}$ of $10 \%$ cetyl trimethyl ammonium bromide and $75 \mu$ of $10 \%$ sodium dodecyl sulfate. Samples were centrifuged $(14,000 \mathrm{rpm}$ for $10 \mathrm{~min})$ and the supernatant was transferred to new microfuge tubes, where $200 \mu$ of 3 M sodium acetate was added. The tubes were incubated on ice for $10 \mathrm{~min}$ and then centrifuged at $14,000 \mathrm{rpm}$ for $10 \mathrm{~min}$ at room temperature. The clear supernatant was collected in a new microfuge tube and the aqueous phase was extracted using an equal volume of chloroformisoamyl alcohol (24:1). The DNA was precipitated with isopropyl alcohol, washed with $70 \%$ ethyl alcohol, and then resuspended in $50 \mu \mathrm{l}$ of Tris-EDTA buffer (10 mM Tris-Cl and $0.1 \mathrm{mM}$ EDTA, $\mathrm{pH}$ 8). The concentration and quality of total DNA was determined using a microvolume spectrophotometer (NanoDrop Technologies, Wilmington, DE).

Primer design. A ' $\mathrm{Ca}$. L. solanacearum'-specific primer set was designed based on a conserved region between the $16 \mathrm{~S}$ and $23 \mathrm{~S}$ rDNA genes. Nucleotide sequences available in the National Center for Biotechnology Information (NCBI) database from ' $\mathrm{Ca}$. $\mathrm{L}$. solanacearum' (GenBank accession CP002371) and other closely related species ('Ca. L. asiaticus' [GenBank accession NC_012985], 'Ca. L. americanus' [GenBank accession FJ263695], ' $C a$. L. africanus' [GenBank accession U61360], and ' $C a$. L. europaeus' [23] [GenBank accession FN678796]) were compared with CLUSTAL X Multiple Sequence Alignment (28). A variable region was found within the aligned region that could be used to differentiate ' $\mathrm{Ca}$. L. solanacearum' from closely related species and, from this region, forward and reverse primers specific for ' $\mathrm{Ca}$. L. solanacearum' were designed. The sequences of the forward
(Lso TX 16/23 F) and reverse (Lso TX 16/23 R) primers were 5'AATTTTAGCAAGTTCTAAGGG- $3^{\prime}$ and $5^{\prime}$-GGTACCTCCCAT ATCGC-3', respectively (Fig. 1).

To identify a species-specific primer outside the $16 \mathrm{~S}$ rDNA gene, the $a d k$ housekeeping gene was chosen as a target. Nucleotide sequences from ' $C a$. L. solanacearum' and the only other closely related species (' $\mathrm{Ca}$. L. asiaticus') for which sequence data was available in the NCBI database were compared as above using CLUSTAL X Multiple Sequence Alignment. From a variable region flanking this housekeeping gene, ' $\mathrm{Ca}$. $\mathrm{L}$. solanacearum'-specific forward (Lso adk F) and reverse (Lso adk R) primers were designed: 5'-GCGCCACACTAACATCTCCTT CC-3' and 5'-CGCAGCAGTATGAGGGCC-3', respectively. Using this methodology, other housekeeping genes from ' $\mathrm{Ca}$. $\mathrm{L}$. solanacearum' were evaluated, including $a d k, g r p E, k d o, f u m C$, $g d h$, and $d n a G$.

The newly designed forward and reverse primers were optimized $\left(\mathrm{T}_{\mathrm{m}}\right.$ selection, lack of stem loop formation, and lack of self annealing) using the Oligonucleotide Properties Calculator (www.basic. northwestern.edu/biotools/oligocalc.html). The primers also were checked for sequence homology to other organisms using BlastN and Primer-Blast. The primers shared $100 \%$ sequence identity only with the ' $\mathrm{Ca}$. L. solanacearum' sequences in GenBank.

In addition to the newly designed primers, the previously published LsoF/OI2c primer set (12) directed at the 16S rDNA gene was used for pathogen detection. Primers for potato $\beta$-tubulin amplification also were included in some experiments: Btub1F $5^{\prime}-$ TGATTTCCAAGGTAAGGGAGGA-3' and Btub1R 5'-CATGTT GCTCTCGGCTTCAG-3' (32). Amplification of the $\beta$-tubulin gene from potato was used as a positive control to indicate the quality of the DNA extractions. All primers were custom synthesized (IDT Incorp).

Table 1. Number of samples of different plant parts from zebra chip disease-symptomatic potato collected in Texas, Kansas, and Nebraska and healthy glasshouse plants

\begin{tabular}{|c|c|c|c|c|c|c|}
\hline \multirow[b]{2}{*}{ Locations } & \multicolumn{6}{|c|}{ Number of samples collected } \\
\hline & Tuber & Root & Stem & Petiole & Leaf & Total \\
\hline Bushland, Texas & 14 & 0 & 5 & 1 & 5 & 25 \\
\hline Weslaco, Texas & 2 & 0 & 9 & 0 & 9 & 20 \\
\hline McAllen, Texas & 3 & 3 & 3 & 0 & 3 & 12 \\
\hline Spring lake, Texas & 6 & 0 & 6 & 0 & 6 & 18 \\
\hline Olton, Texas & 3 & 0 & 3 & 0 & 3 & 9 \\
\hline Dalhart, Texas & 10 & 10 & 10 & 0 & 6 & 36 \\
\hline Garden City, Kansas & 5 & 0 & 5 & 0 & 5 & 15 \\
\hline Bridgeport, Nebraska & 6 & 0 & 2 & 0 & 2 & 10 \\
\hline Glasshouse psyllid-exposed plants & 11 & 2 & 6 & 2 & 5 & 26 \\
\hline Glasshouse psyllid-free plants & 3 & 3 & 3 & 3 & 3 & 15 \\
\hline Total & 63 & 18 & 52 & 6 & 47 & 186 \\
\hline
\end{tabular}

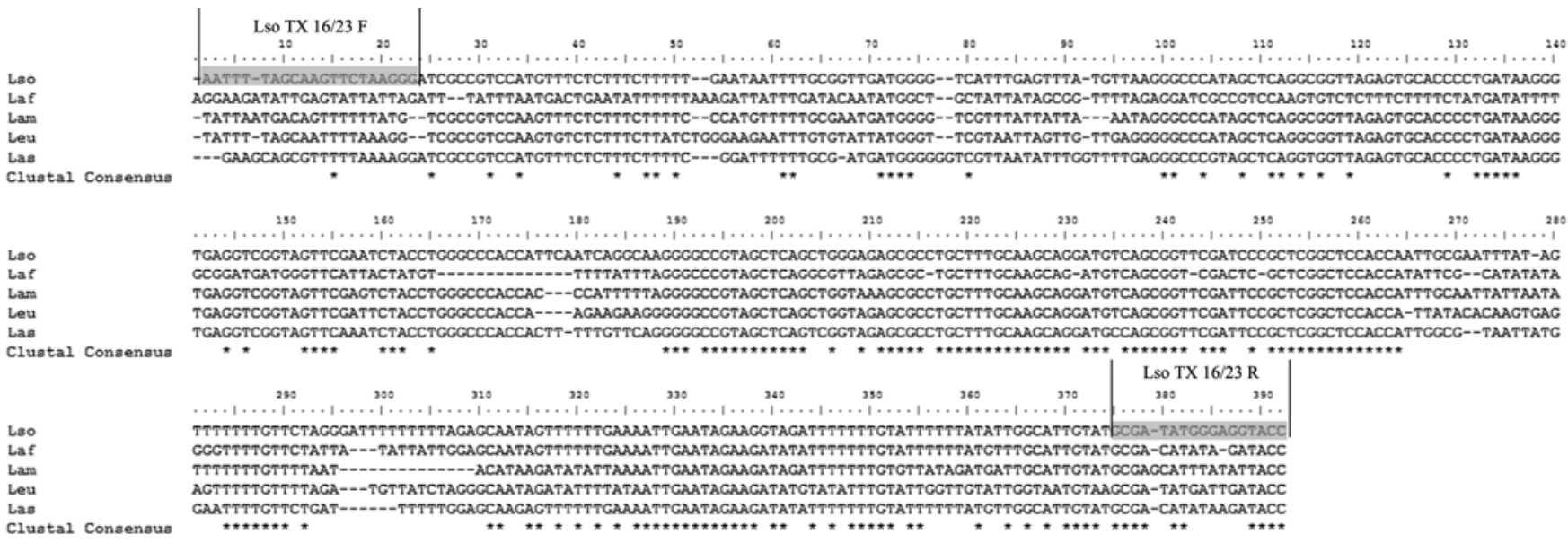

Fig. 1. Multiple sequence alignment of $16 \mathrm{~S} / 23 \mathrm{~S}$ rDNA intergenic region of 'Candidatus Liberibacter solanacearum' (Lso), 'Ca. L. asiaticus' (Las), 'Ca. L. americanus' (Lam), and 'Ca. L. africanus' (Laf), and 'Ca. L. europaeus' (Leu). Asterisks indicate identical nucleotides. 
PCR amplification. PCR amplification was performed in $25-\mu 1$ reactions (1× PCR buffer, $0.5 \mu \mathrm{M}$ each of the primers, $200 \mu \mathrm{M}$ each of the four dNTPs, $0.5 \mathrm{U}$ of Phusion polymerase [Finnzyme], and $100 \mathrm{ng}$ of DNA extract). An ABI Geneamp 9700 thermocycler (Applied Biosystems, Foster City, CA) was used for PCR. Cycle parameters were initial denaturation at $98^{\circ} \mathrm{C}$ for $30 \mathrm{~s}$, followed by 35 cycles of amplification $\left(98^{\circ} \mathrm{C}\right.$ for $10 \mathrm{~s}$, a primer-specific annealing temperature for $20 \mathrm{~s}$, and $72^{\circ} \mathrm{C}$ for $30 \mathrm{~s}$ ), and then a final extension at $72^{\circ} \mathrm{C}$ for $7 \mathrm{~min}$. The annealing temperature was optimized for each primer set by performing PCR over an annealing temperature gradient from 53 to $63^{\circ} \mathrm{C}$. The annealing temperatures used for the LsoF/OI2c, Lso TX 16/23 F/R, and Lso adk F/R primer sets were 62,55 , and $60^{\circ} \mathrm{C}$, respectively. PCR products were examined by gel electrophoresis and verified as necessary by sequencing (Gene Technology Lab, Texas A\&M University, College Station).

PCR Detection of ' $\boldsymbol{C a}$. L. solanacearum'. The ability of the newly designed primer sets to detect ' $\mathrm{Ca}$. L. solanacearum' was determined using six samples (two tubers, two stems, and two leaves) from ZC-symptomatic potato. Amplification of the $\beta$ tubulin gene from potato was used as a DNA quality control. Negative controls included DNA extracted from the glasshouse-
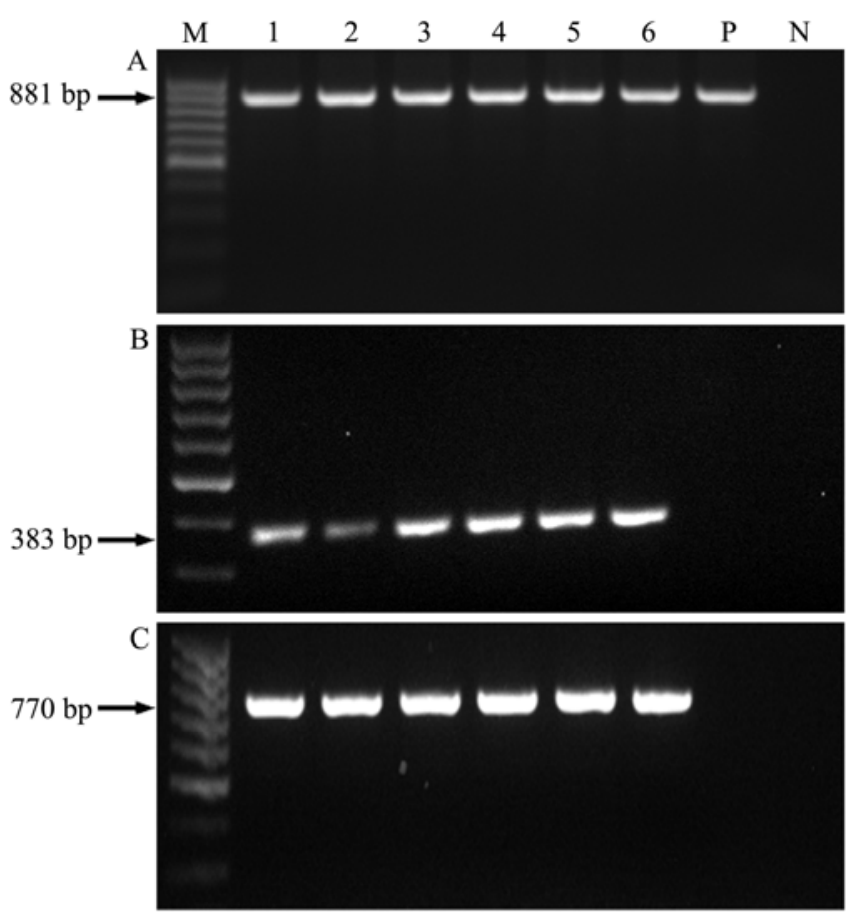

Fig. 2. Polymerase chain reaction amplification from zebra chip disease-symptomatic potato plants using $\mathbf{A}$, the primer pair for amplification of a 881-bp region of the potato $\beta$-tubulin gene (control); B, primer pair Lso TX 16/23 F/R to amplify a 383-bp region of the 'Candidatus Liberibacter solanacearum' 16S/23S rDNA intergenic region; and C, primer pair Lso adk F/R to amplify a 770-bp region of the ' $\mathrm{Ca}$. $\mathrm{L}$. solanacearum' adenylate kinase (adk) housekeeping gene. The $\beta$-tubulin gene amplification serves as a positive control, which indicates the quality of DNA extractions. Lanes 1 and 2, tuber samples; lanes 3 and 4, stem samples; lanes 5 and 6 , leaf samples; lane $\mathrm{P}$, healthy plant $\mathrm{DNA}$; lane $\mathrm{N}$, negative water control. raised plants that were protected from psyllids (healthy plant DNA) and water.

The ability of the newly designed primer sets to detect ' $\mathrm{Ca}$. L. solanacearum' relative to the currently used LsoF/OI2c primer set was determined using DNA isolated from 186 field and glasshouse samples (tubers, roots, stems, petioles, and leaves) of ZC-symptomatic potato tissue (Table 1).

DNA samples extracted from citrus plants symptomatic for HLB (27) were used in a separate experiment to test the specificity of the primer sets for detection of ' $\mathrm{Ca}$. L. solanacearum' versus ' $\mathrm{Ca}$. L. asiaticus'.

To test the sensitivity of the primer sets, PCR was performed on a dilution series of DNA extracted from a ZC-symptomatic plant; DNA was diluted twofold, from 20 to $0.17 \mathrm{ng}$.

\section{Results}

After alignment of the four closely related ' $\mathrm{Ca}$. Liberibacter' spp. for which an rDNA sequence is available, two variable regions within the 16-23S intergenic spacer were identified for the specific amplification of ' $\mathrm{Ca}$. L. solanacearum' (Fig. 1). Similarly, after alignment of the two closely related $\mathrm{Ca}$. Liberibacter' spp. for which $a d k$ gene sequences (606 bp) were available (i.e., ' $\mathrm{Ca}$. L. solanacearum' and ' $C a$. L. asiaticus'), two variable regions flanking the $a d k$ gene were selected for specific amplification in ' $\mathrm{Ca}$. L. solanacearum' (data not shown). The overall nucleotide similarity was $78 \%$ between the $a d k$ genes of ' $C a$. L. solanacearum' and ' $C a$. L. asiaticus'; the ' $C a$. L. solanacearum' primer sequences used to amplify the full $a d k$ gene sequence were variable in ' $\mathrm{Ca}$. L. asiaticus'. In addition to $a d k$, several other housekeeping genes from ' $C a$. L. solanacearum' were evaluated, including grpE, $k d o$, fumC, $g d h$, and $d n a G$. However, only the $a d k$ gene primers gave strong, single-band amplification (data not shown).

The two newly designed primer pairs, Lso TX 16/23 F/R and Lso adk F/R, were predicted to amplify a 383-bp region of the ' $\mathrm{Ca}$. L. solanacearum' $16 \mathrm{~S} / 23 \mathrm{~S}$ intergenic spacer and a 770 -bp product from the ' $\mathrm{Ca}$. L. solanacearum' genome region containing the $a d k$ housekeeping gene, respectively. Both primer pairs detected ' $\mathrm{C} a$. L. solanacearum' in different plant parts, producing single bands of the expected size (Fig. 2). PCR was performed over an annealing temperature gradient from 53 to $63^{\circ} \mathrm{C}$, and annealing temperatures of 55 and $60^{\circ} \mathrm{C}$ were found to give the best single-band amplification of the $16 \mathrm{~S} / 23 \mathrm{~S}$ and adk targets, respectively (data not shown).

To compare the abilities of the previously published and newly developed primer sets to detect ' $C a$. L. solanacearum', the three primer pairs were used to amplify DNA extracted from different plant parts (tubers, roots, stem, petiole, and leaves) from ZC-symptomatic potato plants collected from a wide region (Texas, Kansas, and Nebraska) (Table 1). Both of the newly developed primer pairs (Lso TX 16/23 F/R and Lso adk F/R) detected ' $C a$. L. solanacearum' more frequently in almost all sample types than the existing LsoF/OI2c primer set. There was no difference in detection of the pathogen in petioles, which had a small sample size. Overall detection rates were $49.1 \%$ for the $\mathrm{LsoF} / \mathrm{OI} 2 \mathrm{c}$ primer pair compared with $69.5 \%$ for the Lso TX 16/23 F/R and Lso adk F/R primer pairs. DNA extracts from the greenhouse psyllid-free plants yielded no products with any primer pair (Table 2).

To examine the specificity of the newly developed primers, both the Lso TX 16/23 F/R and Lso adk F/R primer pairs were used to

Table 2. Polymerase chain reaction detection of 'Candidatus Liberibacter solanacearum' in different plant parts from zebra chip disease-symptomatic plants using the existing primer pairs (LsoF/OI2c) and the newly developed primer pairs (Lso TX 16/23 F/R and Lso adk F/R)

\begin{tabular}{|c|c|c|c|}
\hline \multirow[b]{2}{*}{ Plant parts sampled } & \multicolumn{3}{|c|}{ Number of 'C $\mathrm{C}$. L. solanacearum'-positive samples/total number (\%) } \\
\hline & LsoF/OI2c primer set & Lso TX 16/23 F/R primer set & Lso adk F/R primer set \\
\hline Tuber & $36 / 60(60.0)$ & $45 / 60(75.0)$ & $45 / 60(75.0)$ \\
\hline Root & $7 / 15(46.6)$ & $11 / 15(73.3)$ & $11 / 15(73.3)$ \\
\hline Stem & $27 / 49(55.1)$ & $34 / 49(69.3)$ & $34 / 49(69.3)$ \\
\hline Petiole & $3 / 3(100)$ & $3 / 3(100)$ & $3 / 3(100)$ \\
\hline Leaf & $11 / 44(22.0)$ & $26 / 44(59.1)$ & $26 / 44(59.1)$ \\
\hline Lso detection total & $84 / 171(49.1)$ & $119 / 171(69.5)$ & $119 / 171(69.5)$ \\
\hline
\end{tabular}


amplify DNA extracted from ' $\mathrm{Ca}$. L. solanacearum'-infected and ' $C a$. L. asiaticus'-infected plants. Neither of the primer sets produced single bands of the expected size when tested with DNA from samples from ' $\mathrm{Ca}$. L. asiaticus'-infected citrus grown in Florida or India (Fig. 3). Samples from Florida and India represent two different biotypes of ' $\mathrm{Ca}$. L. asiaticus' (2). The quality of the DNA sample from citrus was verified by PCR amplification using ' $\mathrm{Ca}$. L. asiaticus'-specific primers (data not shown). There was some nonspecific amplification of DNA from ' $\mathrm{Ca}$. L. asiaticus'-infected samples using the TX 16/23 F/R primer set, but this did not have the expected product size of 383 bp (Fig. 3).

The sensitivity of the primer sets was tested further using twofold dilutions (20 to $0.17 \mathrm{ng}$ ) of DNA extracted from a ' $C a$. L. solanacearum'-infected plant. Both the Lso TX 16/23 F/R and Lso adk F/R primer pairs were more sensitive than the LsoF/OI2 primers. The low detection limit for the new primers was four times lower $(0.65 \mathrm{ng})$ than the limit $(2.5 \mathrm{ng})$ for the LsoF/OI2 primers (Fig. 4).

\section{Discussion}

Management of ZC disease of potato is dependent on early detection of the pathogen via reliable PCR assays. To date, most primer sets used for PCR detection are based on amplification of the bacterial 16S rDNA gene because of its highly conserved nucleotide sequence among ' $\mathrm{Ca}$. Liberibacter' spp., including the ZC pathogen. This methodology has proven to be useful $(12,33)$ but not consistent in detecting the pathogen in ZC-symptomatic plants. Improved detection requires the development of primers that are more sensitive, yet still able to distinguish between closely related species. Greater sensitivity is especially important because it is now known that the titer in ZC-infected plants initially can be quite low $\left(10^{1}\right.$ to $10^{2}$ genome units per nanogram of DNA extracted from plants) and the pathogen may be unevenly distributed among new and old leaves (11). The two new primer sets developed as part of this study target a conserved intergenic region between the $16 \mathrm{~S}$ and 23S rDNA genes and a conserved bacterial housekeeping gene, $a d k$. Results demonstrate that the new primer sets detected ' $C a$. L. solanacearum' in field and glasshouse samples more consistently than the currently used LsoF/OI2 primer set. For example, the

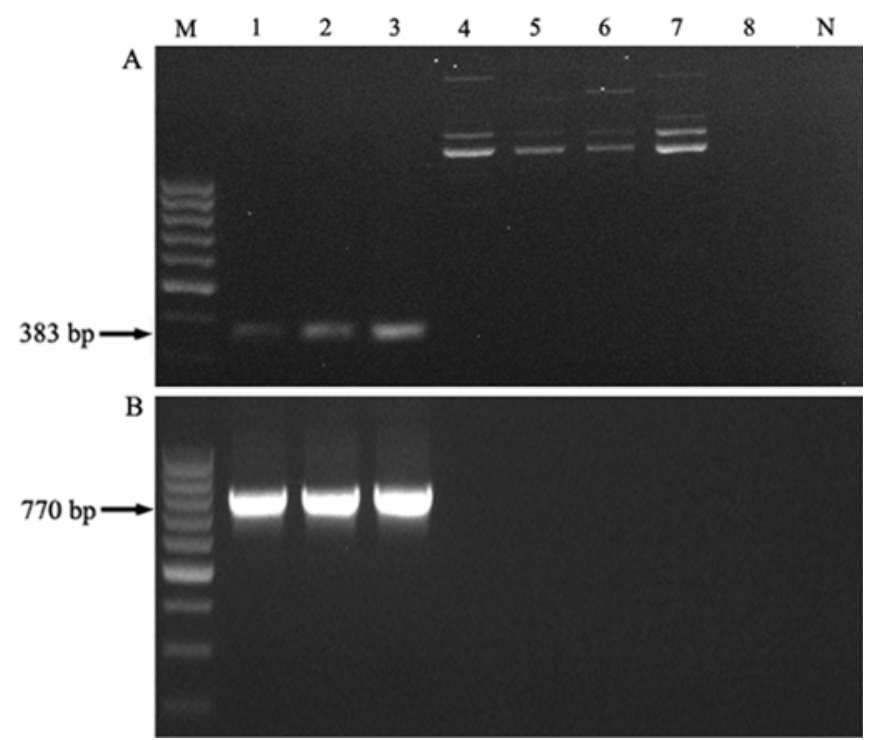

Fig. 3. Specificity of the primers pairs Lso TX $16 / 23 \mathrm{~F} / \mathrm{R}$ and Lso adk F/R for detection of 'Candidatus Liberibacter solanacearum' versus 'Ca. L. asiaticus'. A, Primer pair Lso TX 16/23 F/R amplifies a 383-bp region of the 'Ca. L. solanacearum' 16S/23S rDNA intergenic region and B, primer pair Lso adk F/R amplifies a 770-bp region of the 'Ca. L. solanacearum' adenylate kinase (adk) housekeeping gene. Lane 1, 'Ca. L. solanacearum'- infected potato leaf; lane 2, 'Ca. L. solanacearum'infected potato root; lane 3, 'Ca. L. solanacearum'-infected potato stem; lanes 4-7, 'Ca. L. asiaticus'-infected DNA sample from citrus in Florida; lane 8, 'Ca. L. asiaticus'-infected DNA sample from citrus in India; lane N, water control. newly developed primer sets Lso TX 16/23 F/R and Lso adk F/R shared the same level of detection, about $69.5 \%$, compared with the $49.1 \%$ detection rate for the LsoF/OI2 primer set. The low detection limit for the new primers was four times lower $(0.65 \mathrm{ng})$ than the limit for the LsoF/OI2 primers $(2.5 \mathrm{ng})$, demonstrating greater sensitivity than the LsoF/OI2 primers. The newly developed primers also differentiated between closely related ' $\mathrm{Ca}$. Liberibacter' spp. from citrus.

Although the 16S rDNA is considered the "gold standard" for identification of bacteria at the species level, the $16 \mathrm{~S} / 23 \mathrm{~S}$ intergenic rDNA sequence of ' $\mathrm{Ca}$. L. solanacearum' was targeted because the $16 \mathrm{~S} / 23 \mathrm{~S}$ ribosomal spacer region has been shown to be more variable than the $16 \mathrm{~S}$ rDNA gene and, therefore, more useful for interspecies detection and intraspecies-level comparisons $(1,9)$. Indeed, comparison of the entire region encompassing the $16 \mathrm{~S}$ rDNA gene and 16S/23S rDNA intergenic spacer gene among the five closely related ' $\mathrm{Ca}$. Liberibacter' spp. for which DNA sequence was available demonstrated that the intergenic region had the greatest variability (Fig. 1). Therefore, this region was the most likely to be useful for discriminating among the ' $\mathrm{Ca}$. Liberibacter' spp.

In this study, the utility of using a housekeeping gene for pathogen detection was examined. As noted in other studies (1), it is not always possible to design species-specific probes based on very little sequence variation observed between the 16S rRNA genes. Santos and Ochman (24) suggested that bacterial housekeeping genes (e.g., fusA, gyrB, ileS, and lepA) may be used as alternative phylogenetic markers. Others have suggested the use of other housekeeping genes such as $a d k$, aroE, fumC, gdh, and $p d h C$ $(10,18,19)$. In this study, several housekeeping genes from ' $C a$. L. solanacearum', including adk, grpE, kdo, fumC, gdh, and dnaG, were evaluated. Among these housekeeping genes, the $a d k$ gene was the only gene that gave single-band amplification with high specificity. A constraint of these "alternative" marker genes is that gene sequences in the database are currently limited to ' $\mathrm{Ca}$. $\mathrm{L}$.

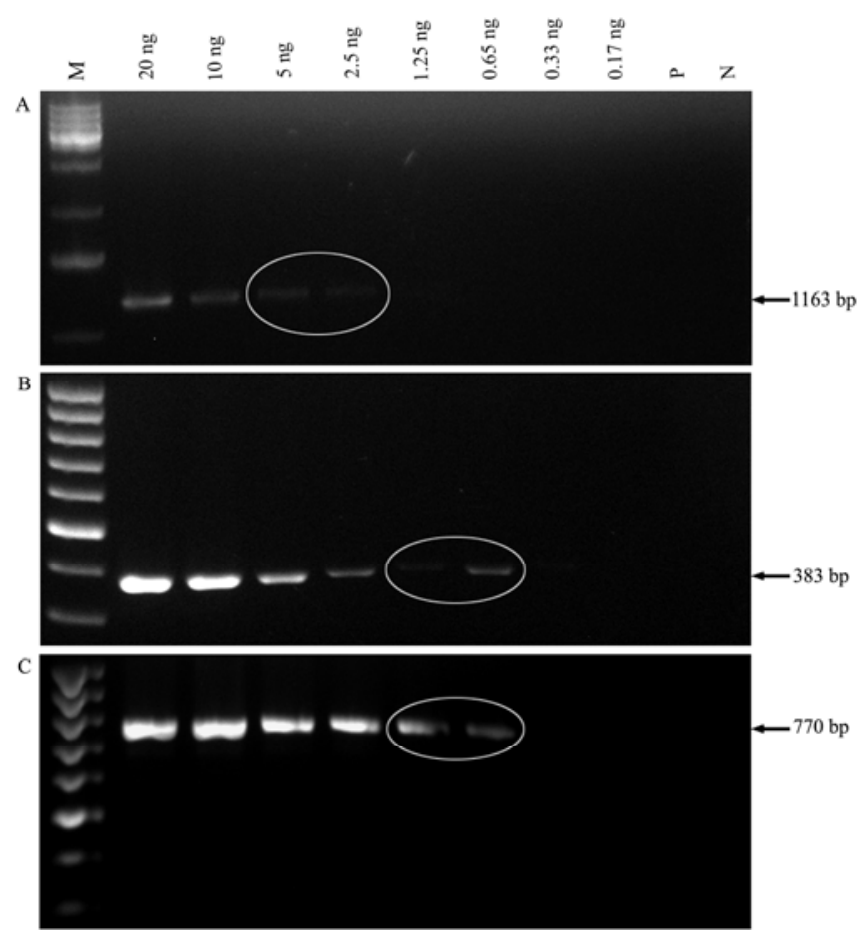

Fig. 4. Sensitivity of the primers pairs LsoF/OI2c, Lso TX 16/23 F/R, and Lso adk F/R for detection of 'Candidatus Liberibacter solanacearum'. A, Primer pair LsoF/OI2c amplifies a 1,163-bp region of the 16S rDNA gene; B, primer pair Lso TX 16/23 F/R amplifies a 383-bp region of the 'Ca. L. solanacearum' 16S/23S rDNA intergenic region; and C, primer pair Lso adk F/R amplifies a 770-bp region of the 'Ca. L. solanacearum' adenylate kinase (adk) housekeeping gene. The DNA sample used in the assay was extracted from a zebra chip disease-symptomatic potato plant and diluted twofold from 20 to $0.17 \mathrm{ng}$. 
solanacearum' and ' $\mathrm{Ca}$. L. asiaticus'. Hopefully, as the usefulness of the $a d k$ gene and other housekeeping genes for detection is recognized, more sequences of 'Ca. Liberibacter' spp. will be deposited.

In conclusion, this study demonstrated that Lso TX 16/23 F/R and Lso adk $\mathrm{F} / \mathrm{R}$ primer sets were highly specific for ' $\mathrm{C} a$. $\mathrm{L}$. solanacearum' isolated from ZC-infected potato plants and more sensitive than the existing primer sets. Use of these new primer sets will improve detection of ' $\mathrm{Ca}$. L. solanacearum' in field and laboratory PCR assays and, thus, contribute to improved ZC disease management.

\section{Acknowledgments}

This work was supported by Texas A\&M AgriLife Research Project Number H-8832 (DCG). We thank C. Rush, G. Schuster, F. Workneh, and D. Henne for field samples; C. Miller and D. Scheuring for supplies and potato for glasshouse experiments; V. Alvarado, O. Duncan, and D. Odokonyero for their technical advice; and N. Wang, University of Florida, for ' $C a$. L. asiaticus' DNA samples from citrus trees grown in Florida and India.

\section{Literature Cited}

1. Barry, T., Collerman, G., Glennon, M., Dunican, L. K., and Gannon, F. 1991. The $16 \mathrm{~S} / 23 \mathrm{~S}$ ribosomal spacer region as a target for DNA probes to identify eubacteria. PCR Methods Appl. 1:51-56.

2. Bové, J. M. 2006. Huanglongbing: a destructive, newly emerging, centuryold disease of citrus. J. Plant Pathol. 88:7-37.

3. Crosslin, J. M., and Munyaneza, J. E. 2009. Evidence that the zebra chip disease and the putative causal agent can be maintained in potatoes by grafting and in vitro. Am. J. Pot. Res. 86:183-187.

4. Doyle, J.J., and Doyle, J. L. 1990. Isolation of plant DNA from fresh tissue. Focus 12:13-15.

5. Gharalari, A. H., Nansen, C., Lawson, D. S., Gilley, J., Munyaneza, J. E., and Vaughn, K. 2009. Knockdown mortality, repellency, and residual effect of insecticides for control of adult Bactericera cockerelli (Hemiptera: Psyllidae). J. Econ. Entomol. 102:1032-1038.

6. Hansen, A. K., Trumble, J. T., Stouthamer, R., and Paine, T. D. 2008. A new huanglongbing species, "Candidatus Liberibacter psyllaurous," found to infect tomato and potato, is vectored by the psyllid Bactericera cockerelli (Sulc). Appl. Environ. Microbiol. 74:5862-5865.

7. Jagoueix, S., Bove, J, M., and Garnier, M. 1994. The phloem-limited bacterium of greening disease of citrus is a member of $\alpha$ subdivision of the proteobacteria. Int. J. Syst. Bacteriol. 44:379-386.

8. Jagoueix, S., Bove, J, M., and Garnier, M. 1997. Comparison of the $16 \mathrm{~S} / 23 \mathrm{~S}$ ribosomal intergenic regions "Candidatus Liberobacter asiaticum" and "Candidatus Liberobacter africanum," the two species associated with citrus huanglongbing (greening) disease. Int. J. Syst. Bacteriol. 47:224-227.

9. Leblond-Bourget, N., Philippe, H. O., Mangin, I., and Decaris, B. 1996. $16 \mathrm{~S}$ rRNA and $16 \mathrm{~S}$ to $23 \mathrm{~S}$ internally transcribed spacer sequence reveals inter and intraspecific Bifidobacterium phylogeny. Int. J. Syst. Bacteriol. 46:102-111.

10. Lee, H.Y., and Côté, J. C. 2006. Phylogenetic analysis of $\gamma$-proteobacteria inferred from nucleotide sequence comparisons of the house-keeping genes $a d k$, aroE and $g d h$ : comparison with phylogeny inferred from 16S rRNA gene sequences. J. Gen. Appl. Microbiol. 52:147-158.

11. Levy, J., Ravindran, A., Gross, D., Tamborindeguy, C., and Pierson, E. 2011. Translocation of 'Candidatus Liberibacter solanacearum', the zebra chip pathogen, in potato and tomato. Phytopathology 101:1285-1291.

12. Li, W., Abad, J. A., French-Monar, R. D., Rascoe, J., Wen, A., Gudmestad, N. C., Secor, G. A., Lee, I-M, Duan, Y., and Levy, L. 2009. Multiplex realtime PCR for detection, identification and quantification of 'Candidatus Liberibacter solanacearum' in potato plants with zebra chip. J. Microbiol. Methods 78:59-65.

13. Li, W., Hartung, J. S., and Levy, L. 2007. Evaluation of DNA amplification methods for improved detection of "Candidatus Liberibacter species" associated with citrus huanglongbing. Plant Dis. 91:51-58.

14. Liefting, L. W., Perez-Egusquiza, W. Z. C., and Clover, G. R. G. 2008. A new 'Candidatus Liberibacter' species in Solanum tuberosum in New Zea- land. Plant Dis. 92:1474.

15. Liefting, L. W., Sutherland, P. W., Ward, L. I., Paice, K. L., Weir, B. S., and Clover, G. R. G. 2009. A new 'Candidatus Liberibacter' species associated with diseases of Solanaceous crops. Plant Dis. 93:208-214.

16. Liefting, L. W., Weir, B. S., Pennycook, S. R., and Clover, G. R. G. 2009. 'Candidatus Liberibacter solanacearum' associated with plants in the family Solanaceae. Int. J. Syst. Evol. Microbiol. 59:2274-2276.

17. López, M. M., Llop, P., Olmos, A., Marco-Noales, E., Cambra, M., and Bertolini, E. 2009. Are the molecular tools solving the challenges posed by detection of plant pathogenic bacteria and viruses? Curr. Issues Mol. Biol. 11:13-46.

18. Maiden, M. C. J. 2006. Multilocus sequence typing of bacteria. Annu. Rev. Microbiol. 60:561-588.

19. Maiden, M. C. J., Bygraves, J. A., Feil, E., Morelli, G., Russell, J. E., Urwin, R., Zhang, Q., Zhou, J., Zurth, K., Caugant, D. A., Feavers, I. A., Achtman, M., and Spratt, B. G. 1998. Multilocus sequence typing: a portable approach to the identification of clones within populations of pathogenic microorganisms. Proc. Natl. Acad. Sci. USA 95:3140-3145.

20. Munyaneza, J. E., Crosslin, J. M., and Upton, J. E. 2007. Association of Bactericera cockerelli (Homoptera: Psyllidae) with "zebra chip", a new potato disease in southwestern United States and Mexico. J. Econ. Entomol. 100:656-663.

21. Parker, M. A., Lafay, B., Burdon, J. J., and van Berkum, P. 2002. Conflicting phylogeographic patterns in rRNA and nifD indicate regionally restricted gene transfer in Bradyrhizobium. Microbiology 148:2557-2565.

22. Parkinson, N., Bryant, R., Bew, J., and Elphinstone, J. 2011. Rapid phylogenetic identification of members of Pseudomonas syringae complex using the rpoD locus. Plant Pathol. 60:338-344.

23. Raddadi, N., Gonella, E., Camerota, C., Pizzinat, A., Tedeschi, R., Crotti, E., Mandrioli, M., Bianco, P. A., Daffonchio, D., and Alma, A. 2011 'Candidatus Liberibacter europaeus' sp. nov. that is associated with and transmitted by the psyllid Cacopsylla pyri apparently behaves as an endophyte rather than a pathogen. Environ. Microbiol. 13:414-426.

24. Santos, S. R., and Ochman, H. 2004. Identification and phylogenetic sorting of bacterial lineages using universally conserved genes and proteins. Environ. Microbiol. 6:754-759.

25. Secor, G. A., V. V. Rivera, J. A. Abad, I. M. Lee, G. R. G. Clover, L. W. Liefting, X. Li, and S. H. De Boer. 2009. Association of 'Candidatus Liberibacter solanacearum' with zebra chip disease of potato established by graft and psyllid transmission, electron microscopy, and PCR. Plant Dis. 93:574-583.

26. Subandiyah, S., Iwanami, T., Tsuyumu, S., and Ieki, H. 2000. Comparison of $16 \mathrm{~S}$ rDNA and $16 \mathrm{~S} / 23 \mathrm{~S}$ intergenic region sequences among citrus greening organisms in Asia. Plant Dis. 84:15-18.

27. Tatineni, S., Sagaram, U. S., Gowda, S., Robertson, C. J., Dawson, W. O. Iwanami, T., and Wang, N. 2008. In planta distribution of 'Candidatus Liberibacter asiaticus' as revealed by polymerase chain reaction (PCR) and real-time PCR. Phytopathology 98:592-599.

28. Thompson, J. D., Gibson, T. J., Plewniak, F., Jeanmougin, F., and Higguns, D. G. 1997. The CLUSTAL_X Windows interface: flexible strategies for multiple sequence alignment aided by quality analysis tools. Nucleic Acids Res. 24:4876-4882.

29. Tomimura, K., Miyata, S. I., Furuya, N., Kubota, K., Okuda, M., Subandiyah, S., Hung, T. H., Su, H. J., and Iwanami, T. 2009. Evaluation of genetic diversity among 'Candidatus Liberibacter asiaticus' isolates collected in southeast Asia. Phytopathology 99:1062-1069.

30. Turner, S. L., and Young, J. P. W. 2000. The glutamine synthetases of rhizobia: phylogenetics and evolutionary implications. Mol. Biol. Evol. 17:309 319.

31. Urwin, R., and Maiden, M. C. J. 2003. Multi-locus sequence typing: a tool for global epidemiology. Trends Microbiol. 11:479-487.

32. Wang, B., Liu, J., Tian, Z., Song, B., and Xie, C. 2005. Monitoring the expression patterns of potato genes associated with quantitative resistance to late blight during Phytophthora infestans infection using cDNA microarrays. Plant Sci. 169:1155-1167.

33. Wen, A., Mallik, I., Alvarado, V. Y., Pasche, J. S., Wang, X., Li, W., Levy, L., Lin, H., Scholthof, H. B., Mirkov, T. E., Rush, C. M., and Gudmestad, N. C. 2009. Detection, distribution, and genetic variability of 'Candidatus Liberibacter' species associated with zebra complex disease of potato in North America. Plant Dis. 93:1102-1115. 